\title{
Development of Basketball Passing Learning Model with A Play Approach to Students Junior High School
}

\author{
Ahmad Rahmadani, Moch. Asmawi, Achmad Sofyan Hanif, Firmansyah Dlis \\ Physical Education Study Program, Jakarta State University, Indonesia \\ ahmadrahmadani@edu.uir.ac.id
}

\begin{abstract}
This research and development aims to produce a product of passing basket ball learning models with a play approach to junior high school students and test the effectiveness of these products. The design of this study refers to the research and development model (Research and Development) of Borg and Gall. Broadly speaking, the development steps for the purposes of this research are carried out in 4 stages, namely: preliminary research, model development planning, evaluation evaluation of model revisions, and model implementation. The effectiveness test of the model uses a basketball passing instrument using the t-test one group pretest-posttest design.The results of the effectiveness test were 6.83 when the pre test increased to 10.25 after the post test, an increase of $28.06 \%$. From the results of data analysis it is evident that there was an increase in the results of the pre test and post test for both male and female students. Based on the results of the study, it was proven empirically that the product results in the form of a passing basketball learning model with an approach to play in junior high school students had very good effectiveness and could be implemented.
\end{abstract}

Keywords : development, model, learning, passing, basketball, playing

\section{Introduction}

Physical education is one of the subject matter included in the school curriculum. In the curriculum are taught various kinds of sports, such as football, basketball, volleyball, athletics, swimming, and others. In basketball learning, passing is one of the basic skills that must be learned, in addition to shooting and dribbling skills. The passing skill itself consists of several simultaneous and continuous movements which are carried out to pass / move the ball. Passing in a basketball game can be done using chest pass, overhead pass, and bounce pass. Dunphy and Hsieh (2009) stated that a chest pass is a standard pass made with two hands from the chest. A bounce pass is a two-handed pass like a chest pass, but it bounces once on the way to its target. An overhead pass is a pass made with two hands over the passer's head.

Based on the analysis of needs in the field obtained by observation in the learning process, many students have difficulty in learning the passing skills because of several things, both technical and non-technical. Until now, the learning method applied by most physical education teachers still conventional tended to make students easily bored in living it. Despite these developments in games and sports teaching, teaching in secondary games to be structured as sports techniques are highly structured lessons (Kirk, 2010). The researcher argues that the learning that has been applied must be improved, but to overcome the boredom in students this learning will be packaged in the form of a game. In addition, researchers also conducted interviews and discussions on physical education teachers in the junior high school. From the results of interviews conducted, the researcher obtained information that most students did not have good basketball passing skills. Mauldon and 
Redfern (1969) suggested that physical educators who have simply mastered a skill and presented a new approach for games teaching.

Based on the problems experienced by students in basketball passing learning, researchers want to develop a passing basketball learning model that fits their learning needs in junior high school. The model that will be developed is a challenging and exciting game concept that makes students enthusiastic to do it, but there is still an element of learning in it. So that students without realizing it still do it but it is not boring because it is a fun designed game without losing the element of mastering the technique in doing passing skills. Besides that the form of learning will be designed to resemble the real situation in a competition so students will be familiar with the conditions when on the field in the real game.

The effort is expected that students will have many and varied experiences of motion so that students will become children who know a lot of motion variations and grow varied motion concepts.Development of physical education learning means completing the existing one by holding a simple, multiplying learning or modifying it. The purpose of this study is to help students move more in interesting and happy situations without losing the essence of physical education itself.

\section{Literature Review}

\subsection{Concept of Model Development}

Some model concepts that are referred to in this study are: 1) Gustafson \& Branch (2002: 1) states that the model is a simple representation of more complex forms, processes and functions of physical phenomena or ideas; 2) McLeod (2007: 296) states the model represents an object or activity called an entity; 3) Wirawan (2011: 79) as a pattern, plan, an example of something that will be made or done or that will be produced; 4) Smith (2009: 77) states the model as a mental picture that helps us understand something that we cannot see or experience directly; 4) Suparman (2014: 107) the model is: reality that describes the structure and order of a concept and displays one form of four forms as follows: verbal or conceptual description, steps of activities or procedures, physical or visual replicas, equations or formula; 5) Smaldino, Lowther and Sussell (2008: 283) models are three-dimensional representations of real objects whose shapes can be larger, smaller and can also be the same as the object they represent;and 6) Puslitjaknov Team (2008: 8-9 models state that the Development Model is the basis for developing the product to be produced. The development model can be a procedural model, a conceptual model, and a theoretical model.

\subsection{Concept of Play Approach}

Playing is a common activity commonly carried out by people who are in a society, such as the environment of children, youth, and adults. Even said children fill a large part of their lives by playing. According to Frost et al., (2012) children play in many ways and for many reasons. There are multiple meanings for play and multiple forms of activities that we call play. The game is a tool for children to explore their world, from what is not recognized to what is known, and from what they cannot do until they are able to do it. According to Mayesky (2009) for adults play is what they do when they have finished their works. It is a form of relaxation. For Young children play is what they do all day. Playing is living and 
living is playing. For a child, playing is an activity they do throughout the day because for children playing is life and life is a game. Children generally really enjoy the game and will continue to do it wherever they have the opportunity, because through playing children learn about what they want to know and ultimately be able to recognize all the events that occur around them.

At the time of playing children can practice all gross motor movements such as running, jumping, jumping and other movements with the aim of their movements even though they are not systematically organized but meaningful or desired that is achieved by functioning their gross motor movements. According to Tracey (2009) why is it playing so important for children? It means that they can learn and explore the world around them safely. It develops skills. What better way to help gross motor skills develop from playing in the garden, learning to climb, kicking a ball, playing games with siblings and parents ?. Playing is a necessity for children, because through playing children will gain knowledge that can develop their abilities. Playing is an activity that is unique and very different from other activities such as learning and work that is always done in order to achieve an end result. Children consolidate their skills that must be realized in various games with different nuances. In this way the child gets additional experience to do other activities. Through children's games can channel their needs without any pressure, coercion or reprimand.

Playing is an instinctive nature of a child. Playing can help develop a child's imagination, creativity, ability to solve problems and improve social skills. According to Schoeboe and Lindqvist (2013), the role of childbirth is that it is an active agent that can be very effective aspects of its own life. When playing, the child imagines and issues ideas that are stored in him. The child expresses the knowledge he has while gaining new knowledge. Studying the world of games means we are aware of the importance of growing children further and helping indirectly, trying to study alternative learning methodologies for them. We must know and must learn the game and try to learn part of our most basic "life side". According to Russ (2004) play major is the arena in which children learn to express emotion, process emotion, modulate and regulate emotion, and use emotion in adaptive ways. This view of play and emotion is a number of recent concepts of emotion and mental health. How our mental development from childhood to adulthood is formed, issues of the rules of life, physical and intellectual development, studying the ancestral cultural results contained in traditional games, etc., which are a small part of the potential and energy part of the playing world that we can use as an alternative learning facility and methodology.

Playing can also improve children's emotional, intellectual and physical abilities through interaction with the environment. Intellectual abilities (thinking power) of children are mostly developed in play activities. Through playing children get the opportunity to discover and experiment with the surrounding environment and be able to feel the emotional process of play activities. White (2008) stated that the means through which children find stimulation, well-being and happiness, and which means through which they grow physically, intellectually and emotionally. Children should be involved in dynamic and fun activities with lots of freedom to move. The play approach will make students interested and enthusiastic about learning, will also develop students' creativity, improve their ability to make decisions, and improve their physical abilities. With the approach to play children get the opportunity to develop their physical conditions such as strength, speed, agility, 
coordination, dexterity that can add to the richness of the child's movements. With this concept children develop in all aspects - physical, social, emotional, and mental.

\section{Research Methodology}

This research is research and development. The purpose of this study was to develop passing basketball learning with an approach to play in junior high school students. This research was conducted for 1 semester from February to July 2017. The research was conducted in several schools in the city of Pekanbaru, including: State of Junior High School 1 Pekanbaru, State of Junior High School Pekanbaru and State of Junior High School 16 Pekanbaru. The following are the number of students participating in the research activities:

Table 1. Research Samples

\begin{tabular}{|l|l|}
\hline Small Scale Trial & 34 students \\
\hline Large Scale Trial & 72 students \\
\hline Effectiveness Test & 72 students \\
\hline
\end{tabular}

The research instrument in this study used a basketball passing test. This test was first validated by experts in the field of basketball and experts in the field of sports tests and measurements. After that a trial of the instrument was carried out. And based on the results of the trial and data analysis, this basketball instrument is declared valid and reliable so that it can be used in research. This study uses the research and development (Research and Development) approach of Borg and Gall.

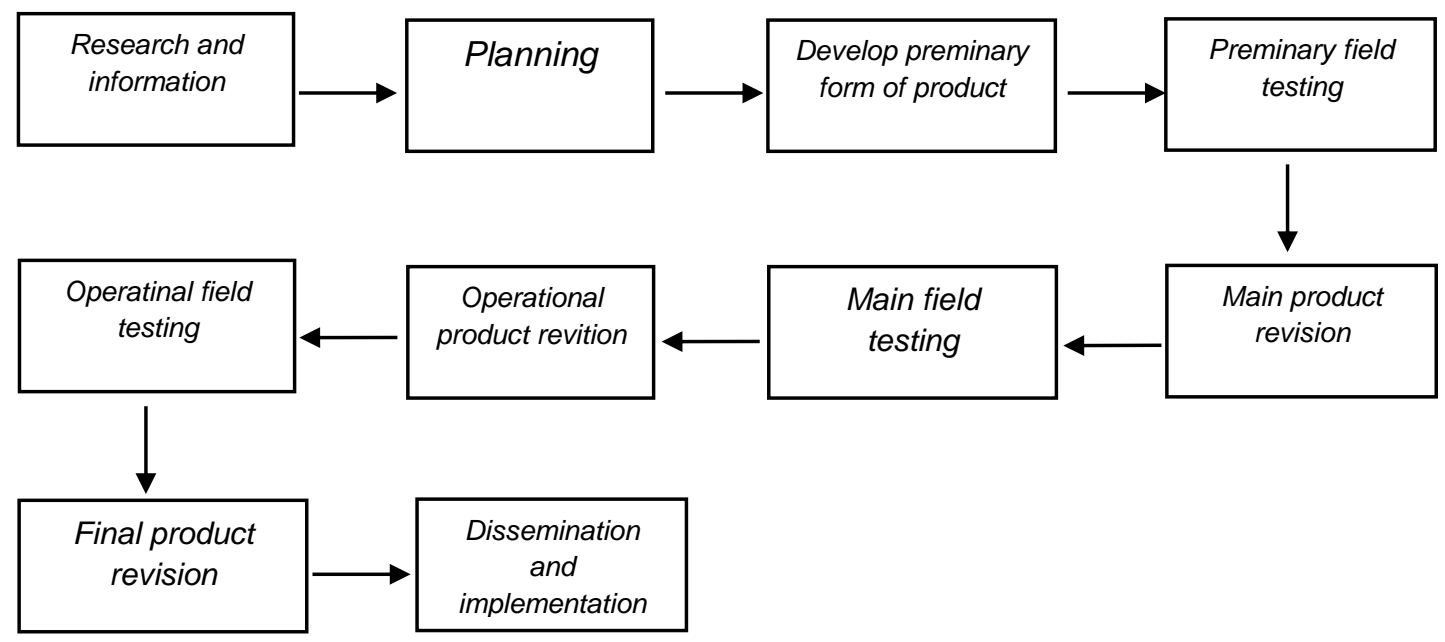

Figure 1. Instructional Design R and D (Borg and Gall, 1983)

In this study, we will use the Borg and Gall development model where the development model guides researchers step by step in detail, and this model also allows learning groups to interact actively because they determine the strategy and type of learning based on the game. The analysis of the tasks described in the Borg and Gall models is arranged in detail and hierarchical special learning goals and repeated trials can provide reliable system results. The product development process, validation carried out through expert testing, and 
limited field trials need to be carried out so that the products produced are useful for improving the quality of learning.

\section{Research Results and Discussion}

\subsection{Preliminary Research}

In the research process of developing this learning model, a preliminary study or needs analysis is first carried out. This was done to determine the condition of passing basketball learning in Pekanbaru City Middle School. Needs analysis is done in various ways, such as: conducting observations in schools, conducting library studies and conducting interviews with physical education teachers.

\subsection{Model Development Planning}

Before the product trial is carried out, development planning for the product will be carried out first. At this stage researchers conduct discussions and collaboration with experts or experts in the field of basketball such as basketball coaches and physical education teachers to discuss the form of passing basketball learning with a play approach that is suitable to be applied to students of First Middle School (SMP). This researcher did to get a product that could later be useful to be applied through physical education learning in schools especially in basketball games.

\subsection{Validation, Evaluation and Model Revision}

This stage is an important part of Research and Development research conducted after the model design has been developed. This stage includes validation, evaluation, and revision of the passing basketball learning model with an approach to play in junior high school (SMP) students which includes: 1) Expert review or expert evaluation by experts in the field of basketball (basketball coach), then do first stage product revision, 2) Conducting trials on small scale (small groups) and then revising the second phase of products, and 3) Conducting trials on large scale (large groups) and then revising the third stage of the product.

\subsection{Expert Judgment}

An expert judgment is an assessment carried out by experts in this matter, experts in the field of basketball. Assessment is carried out to examine the initial product produced and then evaluate the product. Then the experts provide input or advice to researchers for product improvement and after that the first phase of revision is carried out. The product in this study is a passing basketball learning model with a play approach to junior high school students who have been designed and compiled by researchers. This product contains 46 forms of basketball passing learning material with a play approach. The product was then consulted to be reviewed by 2 experts in the field of basketball and 2 physical learning experts. Next to get input and suggestions from the product design development of a passing basketball learning model with a play approach to junior high school students, the method of assessment is that the experts are given a questionnaire containing the draft initial product that will be used in small scale trials (groups small) and accompanied by an evaluation sheet by the expert. After that the experts gave an assessment of the product, assessing whether the product must be repaired, feasible or not worthy of being tested on large groups. 


\subsection{Results of Product Revision Phase I}

In accordance with the input and suggestions submitted by experts / experts in the field of basketball and physical education learning experts, the researchers made several improvements to the design of the passing basketball learning model with a play approach for junior high school students before the trial was conducted to small groups, some of the revisions are described in the following table.

Table 2. Phase 1 Revisions

\begin{tabular}{|c|l|}
\hline NO & \multicolumn{1}{|c|}{ Revised Results } \\
\hline 1. & $\begin{array}{l}\text { Reduction in the number of game material from the } \\
\text { previous 46 material to 41 material }\end{array}$ \\
\hline 2. & The game material consists of: \\
& -16 Game material using chest pass \\
& -12 Game material using a bounce pass \\
& -13 Game material using overhead pass \\
\hline
\end{tabular}

\subsection{Test Results on Small Groups (Small Group Try-out)}

Trials to small groups (small try-out groups) were carried out on small groups as model users who were subsequently revised. The results of the data from the small group trial evaluated by the physical education teacher were analyzed and subsequently used as a basis for revising the passing basketball learning model with a play approach for junior high school students (SMP) before a large group try out (field try-out). In this trial there were 41 game materials after the first revision. In this small group trial involved 34 junior high school students. The purpose of this step is to find out whether the model design that has been developed by the researcher can be carried out well by physical education teachers and is easy to implement by students as the target client (target clientele). Data collection in this step is done through observations and questionnaires which are then analyzed descriptively. The following are the results of trials for small groups evaluated by 2 physical education teachers applied to 34 junior high school students in Pekanbaru.

\subsection{Results of Product Revision Phase II}

In accordance with the input and suggestions that have been submitted by physical education teachers, the researcher made several improvements to the design of the passing basketball learning modelwith the approach of playing for junior high school students before being tested on large groups.

Table 3. Phase II Revisions to Small Group Trial Results

\begin{tabular}{|c|l|l|}
\hline No. & \multicolumn{1}{|c|}{ Expert Advice/ Input } & \multicolumn{1}{c|}{ Follow-Up / Revised Results } \\
\hline 1. & $\begin{array}{l}\text { Mastery of material and class } \\
\text { management strategies need to be well } \\
\text { prepared so that there are no obstacles } \\
\text { in the field such as forgetting material } \\
\text { or haste in time management }\end{array}$ & $\begin{array}{l}\text { An evaluation of the obstacles faced in } \\
\text { the field was conducted and a deepening } \\
\text { of the material together with the teacher } \\
\text { so that classroom management would be } \\
\text { better. }\end{array}$ \\
\hline 2. & The facilities or equipment used need to & Some activities that use the same \\
\hline
\end{tabular}




\begin{tabular}{|c|c|c|}
\hline & $\begin{array}{l}\text { be prepared for several different models } \\
\text { and students must also be involved to } \\
\text { develop tools so that the learning } \\
\text { process can run more effectively and } \\
\text { efficiently }\end{array}$ & $\begin{array}{l}\text { equipment are arranged in such a } \\
\text { way. In addition, students are actively } \\
\text { involved to help organize the equipment } \\
\text { that will be used in conducting the } \\
\text { learning model }\end{array}$ \\
\hline 3. & $\begin{array}{l}\text { Management of materials and tools } \\
\text { needs to be harmonized so that } \\
\text { arrangements can be made more easily }\end{array}$ & $\begin{array}{l}\text { Henceforth each application of the } \\
\text { learning model is arranged in such a } \\
\text { way, for example between applying one } \\
\text { model to another with the same number } \\
\text { of students should be sustainable so that } \\
\text { it is more efficient }\end{array}$ \\
\hline 4. & $\begin{array}{l}\text { Facilities or equipment such as cones, } \\
\text { need to be added so that activities } \\
\text { become more effective }\end{array}$ & $\begin{array}{l}\text { Facilities that support passing basketball } \\
\text { learning such as the availability of } \\
\text { basketball and cones for training are } \\
\text { sufficient }\end{array}$ \\
\hline 5. & $\begin{array}{l}\text { There needs to be a demonstration of } \\
\text { more than one model that is difficult for } \\
\text { students to understand such } \\
\text { as,passing learning models crossing } \\
\text { rectangular formations with } 8 \\
\text { peopleand passing learning models with } \\
\text { a combination of dribbling techniques }\end{array}$ & $\begin{array}{l}\text { Students are given a briefing in the form } \\
\text { of a model demonstration in the form of } \\
\text { a video. There students can see } \\
\text { examples of the application of the model } \\
\text { done by people who are experts, in this } \\
\text { case the model is demonstrated by } \\
\text { students who take part in the basketball } \\
\text { club }\end{array}$ \\
\hline 6. & $\begin{array}{l}\text { Students should be given a summary of } \\
\text { various kinds of movements along with } \\
\text { the name of the movement that will be } \\
\text { carried out during learning so that it is } \\
\text { easier for students to understand } \\
\text { movements and make movements and } \\
\text { can be carried out at home }\end{array}$ & $\begin{array}{l}\text { Students are given a book module } \\
\text { containing passing basketball learning } \\
\text { models with a play approach. It is } \\
\text { expected that students can learn it } \\
\text { outside the learning hours in school so } \\
\text { that it helps students master each } \\
\text { learning model }\end{array}$ \\
\hline 7. & $\begin{array}{l}\text { It is better if the passing learning } \\
\text { model that is difficult to apply several } \\
\text { times is repeated so that students } \\
\text { understand and learning will appear } \\
\text { more alive }\end{array}$ & $\begin{array}{l}\text { Of all the passing basketball learning } \\
\text { models, it is determined that there are } \\
\text { several models that are difficult to } \\
\text { do. As a follow up, the models will be } \\
\text { given demonstrations and repetitions so } \\
\text { that students can apply the model }\end{array}$ \\
\hline
\end{tabular}

\subsection{Test Results for a Large Group (Try-O ut Field )}

The results of the development are products of passing basketball learning models for junior high school (SMP) students who have been tested on a small scale and have been revised, then the next step is to conduct trials on large groups (field try-outs). Based on the results of trials on small groups that have been evaluated by physical education teachers, the researcher then revised the product and obtained 41 forms of passing basketball game material with a play approach consisting of 16 game materials using chest pass, 12 game material using a bounce pass. and 13 game material using overhead passes. All game material 
will be used in trials for large groups (field try-outs). Tests on large groups (field try-outs) were carried out by physical education teachers at Pekanbaru City Junior High School by involving 2 physical education teachers who came from SMPN 9, and 16 SMP Negeri Pekanbaru. The number of subjects used in a large group trial was 72 students. The following are the results of a large group test (filed try-out) conducted on 72 students.

\subsection{Results of Product Revision Phase III}

After the model was tested on small groups and large groups, then the last product revision was carried out. At this stage the data obtained from small and large scale field trials are used as a reference in making the last revision. Revised products are based on input or advice from experts from field trials. From the results of field trials, it was found that the product development of a basketball passing learning model with a play approach to junior high school students had met standardization and was feasible to use without any need to be revised. All aspects have been well tested through field trials both on a small and large scale. There are a number of suggestions from student students during field trials to add variety to the passing basketball learning model with a play approach so that students are more excited, happy, and satisfied through the physical education learning activities taught. With time and cost limitations researchers decided not to add variety to the learning material that had been prepared beforehand. Researchers assume that the passing basketball learning model with a play approach is sufficient for junior high school students.

\subsection{Effectiveness of the Model}

At this stage the effectiveness of the model is tested. The models that will be tested before have gone through the stages of validation, evaluation, and revision of the models developed, then implementing the model. To test the effectiveness of the model using a preexperimental research design with the form of one group pretest - posttest design. The research subjects were 72 students, consisting of 37 male students and 35 female students from 3 Junior High Schools in Pekanbaru City. Furthermore, students are given an initial test or pre-test of passing basketball skills. This test consists of three tests, namely: 1) Tests using chest pass, 2) Tests using a bounce pass, and 3) Tests using an overhead pass. After undergoing a pre-test, students were given treatment in the form of applying a passing basketball learning model with a play approach. Then do the final test or post test using the same instrument. This is done to see if there are differences between the results of the pre test and the post test. The following will be presented with a comparison of the results of the pre test and post using the basketball passing instrument. The research subjects were 72 students consisting of 37 male students and 35 female students.

Table 4. Summary of Effectiveness Test Results for Basketball Passing Tests with t-Test Average Basketball Passing Test Results

\begin{tabular}{llll}
\hline Pretest & Posttest & t count $($ to) & t table $(t))$ \\
\hline 6.83 & 10.25 & 15,534 & 2,045 \\
\hline
\end{tabular}




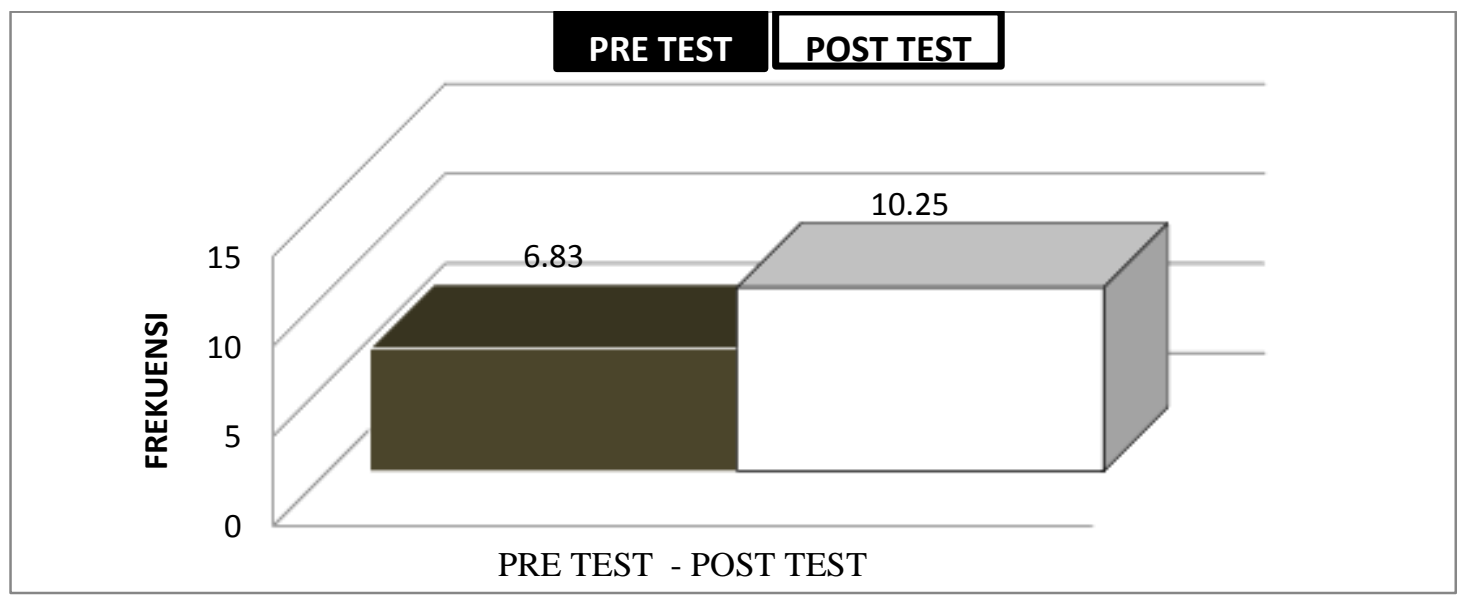

Figure 2 Effectiveness Test Diagram of Pre Test and Post Test Results

From the explanation of the diagram above it can be seen that there was an increase in the results of the pre test and post test conducted by students. When the pre test is done the average value achieved by students is 6.83 , then given a treatment in the form of passing basketball learning with the approach to play. The result is when the post test is done the average student score increases to 10.25. Data analysis also provides an increase from the results of the pre test and post test of $28.25 \%$. The following will describe the results of data analysis in the table below.

Table 5. Pre Test Results and Post Basketball Passing Test

\begin{tabular}{|l|c|c|}
\hline \multicolumn{1}{|c|}{ Statistics } & Pre Test & Post Test \\
\hline Number of Samples & 72 & 72 \\
\hline Mean / Average Value & 6.83 & 10.25 \\
\hline Maximum Value & 9 & 12 \\
\hline Minimum Value & 5 & 7 \\
\hline Standard Deviation & 12.87 & 13.12 \\
\hline
\end{tabular}

\section{Discussion}

From the results of field trials in small groups and large groups, the effectiveness of the passing basketball learning model with the approach of playing in several junior high schools (SMP) in Pekanbaru City has been tested with a research subject of 72 students consisting of 37 male students and 35 female students. Based on the results of the effectiveness tests that have been described previously, it can be seen that the products that have been developed and become the results of this study are considered feasible and fulfill the requirements to be applied to physical education subjects, especially in basketball game material in junior high schools. From the results of the analysis of research data shows that there are differences between the results of the pre-test and posttest passing basketball skills after being given treatment in the form of the application of passing basketball learning models with a play approach. If seen from the average value of 
students when doing the pre test and post test, then there is an increase that can be seen in the table below.

Table 5. Instrument Test Statistical Data

\begin{tabular}{|c|l|c|c|c|}
\hline \multirow{2}{*}{ No. } & \multirow{2}{*}{ Test Instrument } & \multicolumn{2}{|c|}{ Mean } & \multirow{2}{*}{ Gain } \\
\cline { 3 - 4 } & & Pre test & Post test & \\
\hline 1. & Chest pass & 7.29 & 9.19 & $26.03 \%$ \\
\hline 2. & Bounce pass & 6.90 & 8.60 & $24.64 \%$ \\
\hline 3. & Overhead pass & 7.19 & 9.08 & $26.25 \%$ \\
\hline
\end{tabular}

In the table below we will explain the percentage of the increase in the effectiveness test and the average value obtained by students from all three basketball passing instruments based on gender.

Table 6. Test Instrument Statistical Data Based on Gender

\begin{tabular}{|c|l|c|c|c|c|c|c|}
\hline \multirow{2}{*}{ No. } & \multirow{2}{*}{$\begin{array}{c}\text { Test } \\
\text { Instrument }\end{array}$} & \multicolumn{4}{|c|}{ Mean } & \multicolumn{2}{c|}{} \\
\cline { 3 - 8 } & & \multicolumn{2}{|c|}{ Pre test } & \multicolumn{2}{c|}{ Post test } & \multicolumn{2}{c|}{ Gain } \\
\cline { 3 - 8 } & $\mathrm{M}$ & $\mathrm{F}$ & $\mathrm{M}$ & $\mathrm{F}$ & Man & Women \\
\hline 1. & Chest pass & 7.59 & 6.97 & 9.51 & 8.86 & $20.19 \%$ & $27.12 \%$ \\
\hline 2. & Bounce pass & 7.05 & 6.74 & 8.89 & 8.28 & $26.10 \%$ & $22.85 \%$ \\
\hline 3. & Overhead pass & 7.57 & 6.8 & 9.46 & 8.68 & $24.97 \%$ & $27.79 \%$ \\
\hline
\end{tabular}

From the description of the table above it can be seen that when the pre test chest pass instrument the average value obtained by male students is 7.59 greater than female students with an average value of 6.97. After the post test, the average score obtained by male students rose to 9.51, while female students rose to 8.86. Likewise, during the pretest bounce pass instrument the average score obtained by male students was 7.05 greater than female students with an average score of 6.74. After the post test, the average score obtained by male students rose to 8.89 , while female students rose to 8.28 . When the pre test instrument overhead pass pass the average value obtained by male students is 7.57 greater than female students with an average score of 6.8. After the post test, the average score obtained by male students rose to 9.46 , while female students rose to 8.68 .

Then if you see the percentage to increase from pre-test to post test using the three passing instruments. If measured using a chest pass instrument, it turns out that female students have a greater increase than male students, with a percentage of $27.12 \%$ versus $20.19 \%$. But when measured using a bounce pass instrument, male students have a greater increase than female students, with a percentage of $26.10 \%$ versus $22.85 \%$. Then when measured using an overhead pass instrument, the female students returned to greater increases than male students, with a percentage of $27.79 \%$ versus $24.97 \%$. Here is the diagram. 


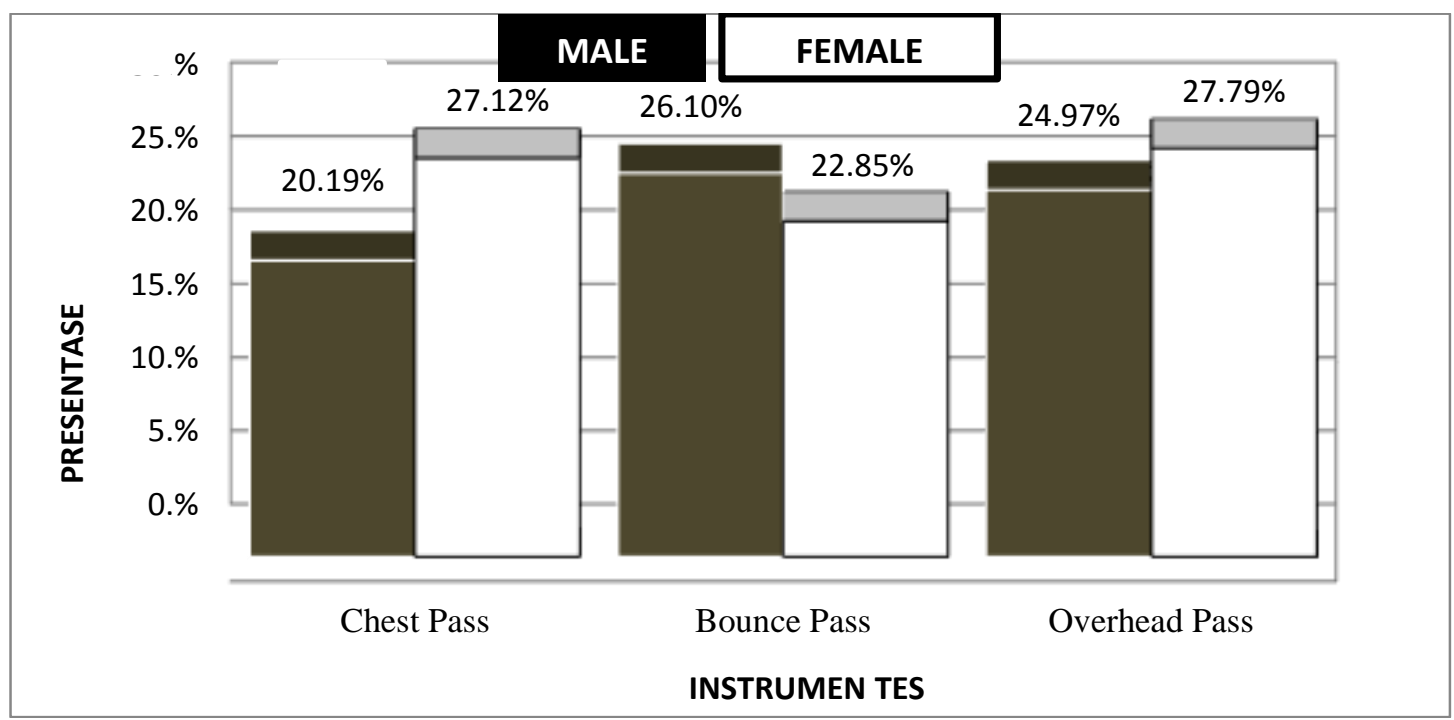

Figure 3. Improved Comparison Chart Instrument Test Based on Gender

From the explanation of the diagram above it can be concluded that both at the time of the pre test and post test the average value obtained by students of male sex is higher than female students. But if you look at the percentage increase from pre-test to post-test using the three passing instruments , female students experience a greater increase than male students.

Based on the results of tests and measurements of passing basketball skills of Middle School students (SMP) using passing basketball instruments showed that the passing basketball learning model with a play approach helped students master mastery passing basketball. Besides that, it is also important to improve students' physical fitness. Student who have been lazy to move during physical education lessons, can be enthusiastic to actively participate in participating in these activities. There are so many benefits felt by students, including: health benefits, students feel happy, satisfied, free to play, and can express their desires. Students also instill moral values during learning such as: being responsible, working together, disciplined, and respecting others. It is hoped that later students will not only be intellectually intelligent, but students will also be emotionally intelligent and can improve each stage of their physical and psychological development so as to make a positive contribution to their future.

\section{Conclusion}

Conclusions from the results of research and discussion can be described as follows:

1. In the form of Research and Development research has produced a product in the form of a passing basketball learning model with an approach to play in junior high school students. The product of this study consists of 41 game material which is divided into three parts, namely: 1) 16 basketball passing learning material with an approach to playing using chest pass, 2) 12 Basketball passing learning material with a playing 
approach using a bounce pass, and 3) 13 Basketball passing learning material with a play approach uses an overhead pass.

2. The passing basketball learning model with the play approach is a model that contains various forms of basketball passing learning material with a play approach. There are three types of passing that are taught, such as: chest pass, bounce pass, and overhead pass. In learning the three types of passing are taught by playing approaches and combined with one another.

3. Based on expert validation and the results of field trials, a product of passing basketball learning model has been produced with a play approach which turns out that overall it is very feasible to be used in the process of learning physical education for junior high school students. This is based on a discussion of the results of product trial analysis, which includes material factors (easy to do, varied, suitability and benefits) and implementation method factors (effectiveness and attractiveness). The product development model is also outlined in the form of a guidebook that makes it easy for physical education teachers to provide material specifically in teaching basketball skills.

4. Based on the results of the model effectiveness test, it has been empirically proven that the product results in the form of a passing basketball learning model with a play approach to junior high school students have very good effectiveness. This is based on the results of the pre test and post test basketball passing skills using instruments that have been tested for validity and reliability. The test results showed that the average value of the results of the pre-test and post-test had increased. So that it can be stated that the passing basketball learning model with an effective playing approach to be used in basketball game learning, especially passing skills for junior high school students.

\section{References}

Bela, B. (1968). Instructional Systems. California: Fearon Publishers.

Barnett A. Lynn. Developmental of Play for Children. Journal of Leasure Research. Vol 22, No. 2, p.138-153. 1990

Bavli, Ozhan. Investing into the Effects of Eight Weeks os Step 1: Aerobic Dance Practice on Static Balance, Flexibility and Selected Basketball Skills in Young Basketball Players . Journal of Education and Training Studies Vol 4, No.5, May 2016, p.233238. ISSN: 2324-8068.

Burns, B., \& Dunning, M. (2010). Basketball: Step by Step . New York: The Rosen Publishing Group.

Butu Ioana Maria, Catona George Cristian, Teoderescu Simona Anemari, and Gheorghe Ioana Georgeta. Theoretical Approaches Regarding the Development of Learning in Physical Education Lessons. Journal of Physical Education and Sport, 2017, Issue 5, Art 232, p.2218-2221. ISSN: 2247-8051.

Claudio Farias, Carla Valerio, and Isabel Mesquita, Sport Education as a Curriculum Approach to Student Learning of Invasion Games: Effects on Game Performance and Game Involvement . Journal of Sport Science and Medicine, Volume 17, Issue 1, p. 5665, March 2018. ISSN: 1303-1968.

Cheryl, A, C. (2004). Motor Learning and Control for Practitioners. New York: McGrawHill. 
Cornel, Catanescu. Elaborating the Experiment Abilities in Basketball Abilities in Basketball at the Age of 11-13 Years Old. Journal of Physical Education and Sport Volume 20, No.3 2008. p. 80-84. ISSN: 1582-8131.

Danny, K. (2008). Fundamental Basketball: First Step To Win. Jakarta: Karang Turi Media.

David, L, G., \& John, C, O. (2006). Understanding Motor Development: Infant, children, adolescent. New York: Mc Graw Hill.

Diana, M. (2010). Psychology of Playing Early Childhood . Jakarta: Kencana.

Donna, J, C., \& Suzanne, T, M. (2012). Functional Movement Development . Missouri: Elsevier.

Edward, H, M. (2010). Motor Learning and Control . USA: Wadsworth.

Emzir. 2008. Educational Research Methods . Jakarta: Rajawali Press.

Farnoosh Fotrousi, Jaleh Bagherly, and Abdollah Ghasemi. The Compensatory Impact of the Mini Basketball Skills on the Progress of Fundamental Movements in Children . Procedia-Social and Behavioral Sciences Volume 46, 2012, p.5206-5210.

Ference, M. (2015). Necessary Conditions of Learning . New York: Routledge.

Frost, L, J et al. (2012). Play Child Developme nt. USA: Pearson.

Hariwijaya. (2009). PAUD Launches the Potential of Children with Early Education . Yogyakarta: Mahadika Publicity.

Ivy, S., \& Ditte, W, L. (2013). Children's Play and Development . Heidelberg: Springer.

Jan V, D, A et al. (1999). Design Approaches and Tools in Education and Training . London: Kluwer Academic Publisher.

Jerry V, K et al. (2008). Basketball Skills and Drills . USA: Human Kinetics.

Julia, M. (2008). Playing, Laughing and Learning with Children on the Autism Spectrum . London: Jessica Kingsley Publisher.

Kathy, M. (2007). Coaching Basketball Technical and Tactical Skills . USA: Human Kinetics.

Joyce, B et al. (2009). Model of Teaching . New Jersey USA: Allyn and Bacon.

Keith, M., \& Greg, K. (2015). Youth Basketball Coaching . USA: Human Kinetics.

Konstapoulos Nikolaos, Bekris Evangelos, Apostolidis Nikolaos and Kavroulakis Emmanouil, The Effect of Balance and Proprioception Training on Amateur programs Basketball Players Passing Skills, Journal of Physical Education and Sport, 12 (3), Art 47, pp.316-323, 2012 ISSN: 2247-8051.

Mary, M. (2009). Creative Activities for Young Children 9th Ed: Play, Development, and Creativity. New York: Delmar Publishers Inc.

Mei-Yao Huang, Hsin-Yu Tu, Wen-Yi Wang, Jui-Fu Chen, Ya-Ting Yu, and Chien-Chih Chou. Effects of Cooperative Learning and Concept Mapping Interventions on Critical Thinking and Basketball Skills in Elementary Schools. Elsevier: Thinking Skills and Creativity. Volume 23, March 2017, p. 207-216.

Morgan, W., \& Joe, W. (2012). Successful Coaching Basketball . USA: Human Kinetics.

Nancy, L. (2012). Basketball For Woman . USA: Human Kinetics.

Robert, B, M. (2009). Intructional Design: The ADDIE Approach. New York: Springer.

Richard, A, M. (2011). Motor Learning and Control . New York: McGrawHill.

Tahhread Ahmed, The Effect of Upper Extremity Fatigue on Grip Strength and Passing Accuracy in Junior Basketball Players . Journal of Human Kinetics volume 37/2013, 71-79 DOI: 10.2478 / hukin-2013-0027.

Tracey, B. (2009). Messy Play: Ideas and Activities for Children with Special Needs . London: Jessica Kingsley Publisher. 